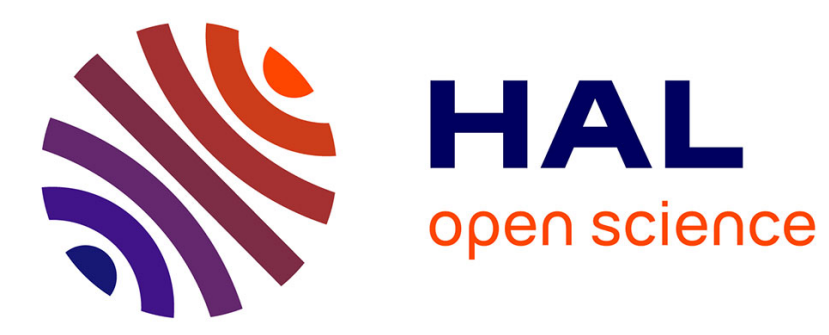

\title{
Thermal investigations of Ti and Ag-doped bioactive glasses
}

Eric Wers, Hassane Oudadesse, Bertrand Lefeuvre, Bruno Bureau, Odile Merdrignac-Conanec

\section{- To cite this version:}

Eric Wers, Hassane Oudadesse, Bertrand Lefeuvre, Bruno Bureau, Odile Merdrignac-Conanec. Thermal investigations of $\mathrm{Ti}$ and Ag-doped bioactive glasses. Thermochimica Acta, 2014, 580, pp.79-84. 10.1016/j.tca.2014.02.001 . hal-00984219

\section{HAL Id: hal-00984219 https://hal.science/hal-00984219}

Submitted on 16 Jun 2014

HAL is a multi-disciplinary open access archive for the deposit and dissemination of scientific research documents, whether they are published or not. The documents may come from teaching and research institutions in France or abroad, or from public or private research centers.
L'archive ouverte pluridisciplinaire HAL, est destinée au dépôt et à la diffusion de documents scientifiques de niveau recherche, publiés ou non, émanant des établissements d'enseignement et de recherche français ou étrangers, des laboratoires publics ou privés. 


\section{Accepted Manuscript}

Title: Thermal investigations of Ti and Ag-doped bioactive glasses

Author: E. Wers H. Oudadesse B. Lefeuvre B. Bureau O.

Merdrignac-Conanec

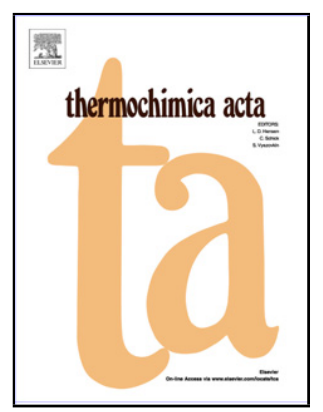

PII: $\quad$ S0040-6031(14)00043-4

DOI: $\quad$ http://dx.doi.org/doi:10.1016/j.tca.2014.02.001

Reference: $\quad$ TCA 76765

To appear in: $\quad$ Thermochimica Acta

Received date: $\quad 20-11-2013$

Revised date: 23-1-2014

Accepted date: $\quad 3-2-2014$

Please cite this article as: E. WersH. OudadesseB. LefeuvreB. BureauO. MerdrignacConanec Thermal investigations of $\mathrm{Ti}$ and Ag-doped bioactive glasses (2014), http://dx.doi.org/10.1016/j.tca.2014.02.001

This is a PDF file of an unedited manuscript that has been accepted for publication. As a service to our customers we are providing this early version of the manuscript. The manuscript will undergo copyediting, typesetting, and review of the resulting proof before it is published in its final form. Please note that during the production process errors may be discovered which could affect the content, and all legal disclaimers that apply to the journal pertain. 


\title{
Thermal investigations of Ti and Ag-doped bioactive glasses.
}

\author{
E. Wers, H. Oudadesse*, B. Lefeuvre, B. Bureau, O. Merdrignac-Conanec
}

University of Rennes 1, SCR, UMR CNRS 6226, 263 av. du Général Leclerc, 35042

Rennes, France

\section{Corresponding author: hassane.oudadesse@univ-rennes1.fr}

\begin{abstract}
The purpose of this paper is to explore the effect of titanium and silver on the characteristic temperatures of 46S6 glass and the excess entropy. The results show that the adding of these metals in the chemical composition does not affect the amorphous character of glasses. The introduction of these elements greatly reduces the melting temperatures of glasses and involves similar variations on the crystallization and glass transition temperatures. These elements also increase the thermal stability of glasses. The excess entropy calculations show a decrease when the content of $\mathrm{Ti}$ or Ag increases. Contrary to crystals, synthesized glasses have entropy different to zero at $T=0 \mathrm{~K}$.
\end{abstract}

Keywords: Titanium, Silver, Excess entropy, Thermal characteristics.

1 Introduction: Bone grafts (heterografts, xenografts) are capable of transmitting viruses and/or infections. The synthetic biomaterials are an excellent alternative to replace grafts because they are available in unlimited quantities, they can be adapted to the needs of patients and their chemical composition can be controlled [1-2]. The efficiency of the bioactive glasses is well proven [1-3] and they are the subject of numerous studies and many developments all over the world in order to improve their properties for biomedical use.

Hench has discovered the first bioactive glass: $45 \mathrm{~S} 5$ or Bioglass ${ }^{\circledR}$ in the quaternary $\mathrm{SiO}_{2}$, $\mathrm{Na}_{2} \mathrm{O}, \mathrm{CaO}$ and $\mathrm{P}_{2} \mathrm{O}_{5}$ system [1-3]. Their bioactive character results of their ability to form a hydroxyapatite layer $\mathrm{Ca}_{10}\left(\mathrm{PO}_{4}\right)_{6}(\mathrm{OH})_{2}$ on their surface when they are immersed in a simulated body fluid (SBF) [4-5-6]. The hydroxyapatite is the major inorganic compound of the human bone. It induces a bone bonding improving the bone growth.

However, complications such as bacterial infections may occur during implantation of a biomaterial. The particularity of this investigation is based on the introduction of $\mathrm{Ag}$ and $\mathrm{Ti}$ in 
the pure bioactive glass 46S6. Each of these chemical elements presents interesting biological properties that may expand the field of use of bioactive glasses.

Titanium is present in several inert biomaterials such as hip prosthesis made of titanium alloy, screws and plates to repair bone damages. It does not induce inflammatory response because it is a good biocompatible material [7]. It is also used in the materials for aerospace because it has high mechanical properties. It allows reinforcing biomaterials [7].

The antibacterial properties of the silver ion $\mathrm{Ag}^{+}$have been used for many years in the medicine [8]. A lot of studies on 12 species of bacteria including E.Coli [9-10] confirmed its biological properties. The introduction of silver into implants is promising method in reducing the infection rate, while exhibiting low toxicity towards cells and tissues [11-12]. Moreover, its use in the surgical tools (pins, scalpel) decreases bacterial colonization and infections [13]. The incorporating of silver ions into the glass matrix allowed the controlled delivery of this anti-bacterial agent at the site of the bone defect [14]. News studies about bioactive glasses doped with silver showed that these glasses have a bacteriostatic potential and induce bacteria reactions [8-15].

Glasses are composed of network forming, modifying and intermediate oxides. They present an amorphous character reflecting a structural disorder. Metal elements introduced in the glass matrix may involve specific changes on thermal behavior. In a previous work, the introduction of zinc has showed a decrease of the fusion temperature and the excess entropy of the pure glass 46S6 [16]. In the glassy matrix, if there are no enough alkaline ions, the intermediate element will be a network modifier by creating two oxygen bridges. Conversely, if there are enough alkaline ions, the intermediate element will be a network former [16-17]. Studies have showed the impact of silver and titanium on the thermal properties.

Numerous researches about borophosphate glasses have showed the effect of the addition of $\mathrm{TiO}_{2}$ on their thermal characteristics. The results showed a non-linear increase of glass transition temperature [18]. In glasses in the ternary system $\mathrm{Na}_{2} \mathrm{O}-\mathrm{TiO}_{2}-\mathrm{P}_{2} \mathrm{O}_{5}$, the addition of $\mathrm{TiO}_{2}$ (from 0 to $5 \mathrm{~mol} \% \mathrm{TiO}_{2}$ ) resulted in a non linear increase of glass transition temperature and dilatation softening temperature. The increase of $\mathrm{TiO}_{2}$ content involves the increase of the contribution of the surface crystallization mechanism. With the increase of $\mathrm{TiO}_{2}$ content, the temperature of maximum nucleation rate is also gradually shifted from a value close to the glass transition temperature towards the crystallization temperature. The chemical durability of the glasses without titanium oxide is very poor, but with the replacement of $\mathrm{Na}_{2} \mathrm{O}$ or $\mathrm{P}_{2} \mathrm{O}_{5}$ by $\mathrm{TiO}_{2}$, it increases sharply [19]. It has been proved shown that $\mathrm{TiO}_{2}$ changes from a glass network former to a glass network modifier with increasing $\mathrm{TiO}_{2}$ content in this system [20]. 
$\mathrm{TiO}_{2}$ is also an effective nucleating agent for promoting the crystallization of apatite and wollastonite.

In chalcogenide glasses, the introduction of a content of silver causes several changes in the thermal behavior. Indeed, the thermal stability and the glass-forming ability increase with the Ag content. Results show that $\mathrm{Se}_{80.5} \mathrm{Bi}_{1.5} \mathrm{Te}_{16} \mathrm{Ag}_{2}$ composition is thermally more stable and has a little tendency to crystallize in comparison to other compositions without silver. The increase in thermal stability with increasing $\mathrm{Ag}$ concentration is attributed to an increase in the cohesive energy [21]. Moreover, the introduction of silver in polyurethane composites improves and increases both the thermal conductivity and the stability in comparison with a reference polyurethane sample without silver [22]. In Ag-As-Se chalcogenide glasses, the enthalpy of primary crystallization decreases with increasing Ag content, accompanied by an increase of the activation energy of primary crystallization and the thermal stability of the supercooled liquid, which suggests a change of the crystallization mechanism [23]. Moreover, the glass transition temperature is independent of the Ag content [23]. For other materials, for example syndiotactic polystyrene, the adding of silver enhances the thermal stability, probably due to the higher thermal conductivity that silver exhibits [24].

This work comes after the thermal study of bioactive glasses doped with zinc [16]. The aim of this study is to investigate the impact of titanium and silver ions on the characteristic temperatures and the excess entropy of bioactive glasses. The excess entropy was calculated according to the changes of thermal characteristics [16]. This entropy represents the difference between the melting entropy of crystal and the entropy of glass [16]. Unlike crystals which have a zero entropy, synthesized glasses have entropy different to zero at $T=0$ $\mathrm{K}$ and versus $T_{\mathrm{f}}[25]$.

\section{Materials and methods}

\subsection{Elaboration of bioactive glasses}

The pure bioactive glass $46 \mathrm{~S} 6\left(46 \mathrm{wt} \% \mathrm{SiO}_{2}, 24 \mathrm{wt} \% \mathrm{CaO}, 24 \mathrm{wt} \% \mathrm{Na}_{2} \mathrm{O}\right.$ and $6 \mathrm{wt} \% \mathrm{P}_{2} \mathrm{O}_{5}$ ) was studied doped by introduction of different concentrations of silver and titanium: 46S6$x \mathrm{Ag}$ and 46S6- $x \mathrm{Ti}$ (where $x=0,0.1,1,5$ and 10 in wt \%).

For the preparation of bioactive glasses, sodium metasilicate $\left(\mathrm{Na}_{2} \mathrm{SiO}_{3}\right)$, silicon oxide $\left(\mathrm{SiO}_{2}\right)$, calcium metasilicate $\left(\mathrm{CaSiO}_{3}\right)$, sodium metaphosphate $\left(\mathrm{Na}_{3} \mathrm{P}_{3} \mathrm{O}_{9}\right)$, silver oxide $\left(\mathrm{Ag}_{2} \mathrm{O}\right)$ and 
titanium oxide $\left(\mathrm{TiO}_{2}\right)$ were weighed and mixed in a polyethylene bottle, for 2 hours using a planetary mixer. $\mathrm{Ag}_{2} \mathrm{O}$ and $\mathrm{TiO}_{2}$ were introduced at the expense of $\mathrm{Na}_{2} \mathrm{O}$ and $\mathrm{CaO}$.

The premixed mixtures were melted in platinum crucibles that were placed in an electric furnace. The first rise of temperature rate was $10^{\circ} \mathrm{C} / \mathrm{min}$ and it was hold at $900^{\circ} \mathrm{C}$ for 1 hour to achieve the decarbonation of all products. The second rise of temperature rate was $20^{\circ} \mathrm{C} / \mathrm{min}$ and it was hold to $1350^{\circ} \mathrm{C}$ for 3 hours. The samples were casted in preheated brass molds, in order to form cylinders of $13 \mathrm{~mm}$ in diameter, and annealed at $565{ }^{\circ} \mathrm{C}$ for 4 hours near the glass transition temperature of each glass [16].

\subsection{Differential Thermal analysis}

Differential Thermal Analysis (DTA) was used to measure the thermal characteristics of different bioactive glasses. The DTA principle is based on the detection of exothermic or endothermic phenomenon. The glass transition temperature $T_{\mathrm{g}}$, the crystallization temperature $T_{\mathrm{c}}$ and the fusion temperature $T_{\mathrm{f}}$ have been recorded using a Setaram Labsys 1600TGDTA/DSC thermal analyzer under $\mathrm{N}_{2}$ gas atmosphere. The onset temperature of crystallization $T_{\text {onset }} \mathrm{c}$ represented the beginning of the crystallization have been recorded. All characteristics temperatures were obtained thanks to SETSOFT software which uses the tangent method. Bioactive glasses were studied under heating rate of $5^{\circ} \mathrm{C} / \mathrm{min}$ raised from room temperature to $1400^{\circ} \mathrm{C} .40 \mathrm{mg}$ of the glass powder was heated in platinum crucible and another empty platinum crucible for use as control. The thermal stability (TS) of bioactive glasses has been expressed by the difference between $T_{\mathrm{g}}$ and $T_{\text {onset }} \mathrm{c}$ introduced by Dietzel [26]:

$$
T S=T_{\text {onset }} \mathrm{C}-T_{\mathrm{g}}
$$

\section{Results and discussion}

\subsection{Characterizations of Ag-doped glasses and Ti-doped glasses.}

In the order to see the impact of a high amount of $\mathrm{Ti}$ or $\mathrm{Ag}$ on the structure of the glass network, measures by X-ray diffraction were undertaken. The diffractograms of bioactive glasses were obtained between 5 and $80\left(2 \theta^{\circ}\right)$ using a Bruker D8 advance diffractometer with 
$\mathrm{Cu} \mathrm{K}_{\alpha}$ radiation. A halo of diffraction, characteristic of an amorphous system, was visible between 24 and $40\left(2 \theta^{\circ}\right)$ for pure and doped glasses. Thereby, a content of $10 \mathrm{wt} \%$ of Ti or Ag introduced in the glass matrix does not affect the amorphous character of these glasses.

To analyze the eventual new chemical bonds formed by introduction of metal elements, analyses by infrared spectroscopy were performed by using Fourier Transformer InfraRed (FTIR) spectrometer Bruker Equinox 55 between 4000 and $400 \mathrm{~cm}^{-1}$ with a resolution of 2 $\mathrm{cm}^{-1}$. The infrared spectra of bioactive glasses are presented in Figure 1.

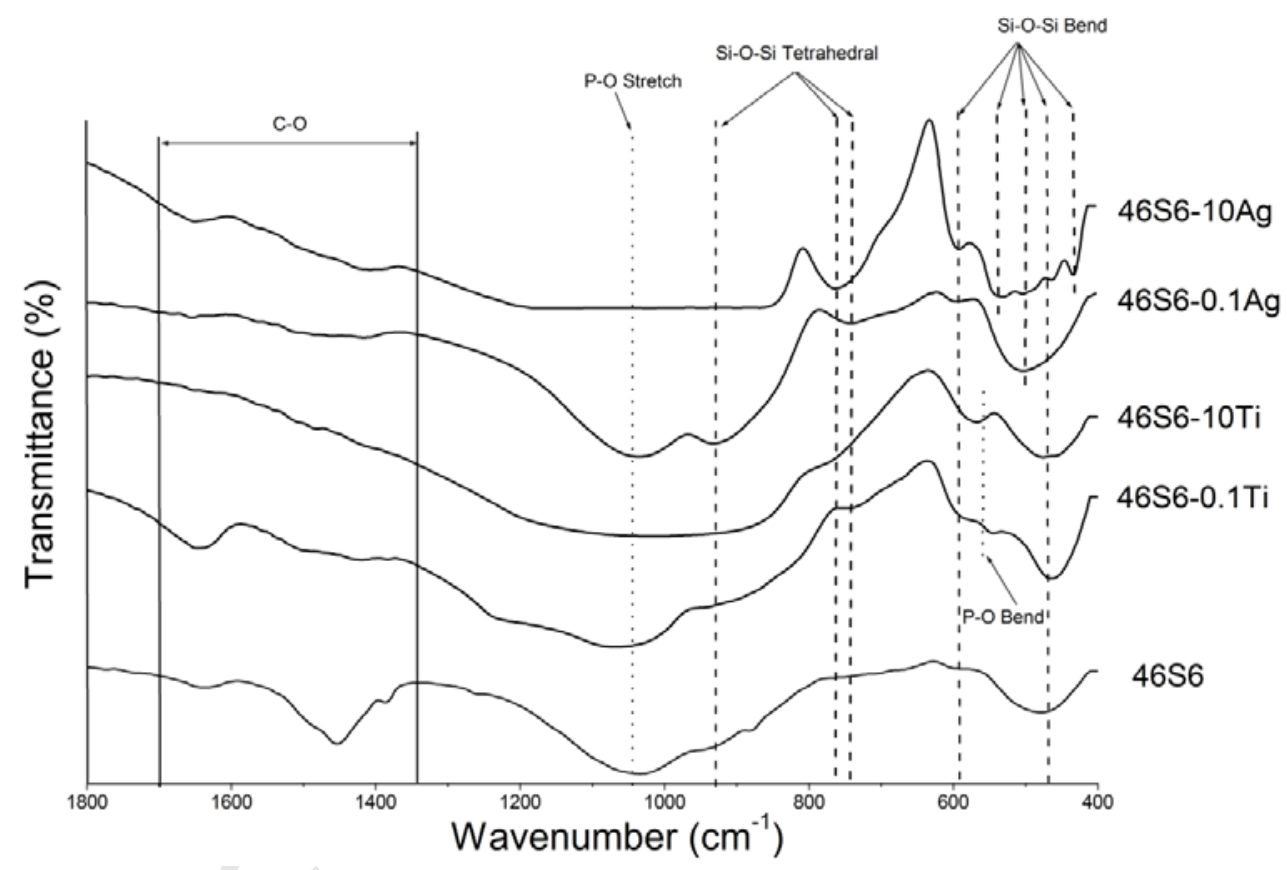

Figure 1: FTIR spectra of pure and doped glasses

For all glasses, bands characteristic of bend vibrations of Si-O-Si bonds are visible at $479 \mathrm{~cm}^{-}$ ${ }^{1}$. Between 1350 and $1700 \mathrm{~cm}^{-1}$, vibrations of $\mathrm{C}-\mathrm{O}$ bonds are due to the carbon dioxide present during the analysis. A band characteristic at $592 \mathrm{~cm}^{-1}$ reveals bend vibrations of Si-O-Si bonds for all glasses except to that of 46S6-10Ag which is more pronounced. For 46S6-0.1Ti and $46 \mathrm{~S} 6-0.1 \mathrm{Ag}$, a band characteristic of Si-O-Si tetrahedral bond is observed at $736 \mathrm{~cm}^{-1}$. When the content of $\mathrm{Ti}$ and $\mathrm{Ag}$ increases, this band is displaced at $757 \mathrm{~cm}^{-1}$. Indeed, at 757 
and $924 \mathrm{~cm}^{-1}$, bands characteristics of tetrahedral vibrations of $\mathrm{Si}-\mathrm{O}-\mathrm{Si}$ bonds are present except for pure glass $46 \mathrm{~S} 6$. The band at $757 \mathrm{~cm}^{-1}$ is more pronounced for 46S6-10Ag. And a stretch vibration of $\mathrm{P}-\mathrm{O}$ bonds is visible at $1050 \mathrm{~cm}^{-1}$ for pure and doped glasses but it is less pronounced for 46S6-10Ag and 46S6-10Ti.

Changes appear according to the doping element introduced in the glass. For 46S6-10Ag, several Si-O-Si bonds were formed at 431, 497 and $536 \mathrm{~cm}^{-1}$. The adding of high content of silver forms chemical bonds in the glass matrix. Moreover, only the Ti-doped glasses reveal a band characteristic of a bend vibration of $\mathrm{P}-\mathrm{O}$ bonds at $557 \mathrm{~cm}^{-1}$. The formation of P-O bond in the Ti-doped glasses could be due to a breaking of $\mathrm{P}=\mathrm{O}$ bond. Silva et al [27] explains that in the glass, with a low content of $\mathrm{TiO}_{2}$, the metaphosphate units are dominant and increasing the content, metaphosphate units are replaced by pyrophosphate units. This could also explain the formations P-O bonds for Ti-doped glasses. Indeed, RMN study in calcium phosphate glasses containing titanium has proved that the introduction of $\mathrm{TiO}_{2}$ in the matrix involves the formation of Ti-O-P bonds [27]. The increase of $\mathrm{TiO}_{2}$ could allow the replacement of a P-O-P bond by a Ti-O-P bond and thus increase the intensities of $\mathrm{P}-\mathrm{O}$ bands at $557 \mathrm{~cm}^{-1}$.

Thereby, the adding of $\mathrm{Ti}$ or $\mathrm{Ag}$ in the glass matrix forms new chemical bonds in the glass matrix: Si-O-Si bonds are formed in the Ag-doped glasses while P-O bonds appear in those doped with titanium. The electronegativity of these elements, most important for silver (Table 1) may explain these differences. Silver ions tend to form more chemical bonds that titanium ions due to its high electronegativity hence the numerous Si-O-Si bonds formed. Metaloxygen bonds form definitely in the glass matrix and thereby, the other chemical bonds are more visible by infrared spectroscopy. These data are important because these formations of chemical bonds may have an influence on the thermal behavior of glasses.

In order to measure the characteristic temperatures and calculate the excess entropy, DTA analyses were performed.

\begin{tabular}{|c|c|c|c|}
\hline Chemical element & Atomic radius $(\mathrm{pm})$ & Electronegativity & Fusion point $\left({ }^{\circ} \mathrm{C}\right)$ \\
\hline $\mathrm{Ag}$ & 160 & 1.93 & 962 \\
\hline $\mathrm{Ti}$ & 176 & 1.54 & 1660 \\
\hline
\end{tabular}

Table 1: Atomic radius, electronegativity and fusion point of $\mathrm{Ag}$ and $\mathrm{Ti}$

\subsection{Influence of Ag and Ti on the thermal characteristics of bioactive glasses.}


In bioactive glasses, the ratio $\mathrm{CaO} / \mathrm{Na}_{2} \mathrm{O}$ was kept constant and equal to 1 because in a previous work concerning the study of $\mathrm{Zn}$-doped glasses, the variation of the $\mathrm{CaO} / \mathrm{Na}_{2} \mathrm{O}$ ratio was involved in the decrease of characteristic temperatures [16]. The introduction of $\mathrm{Na}_{2} \mathrm{O}$ creates two bridges oxygen in the amorphous system. The two negative charges of oxygen are balanced by the charge of $\mathrm{Na}^{+}$pair forming a neutral electrostatic matrix. Thereby, the network structure is modified and changes the glass thermal properties [16]. The introduction of $\mathrm{CaO}$ does not involve any modifications because the two positive charges of $\mathrm{Ca}^{2+}$ are balanced and create two tetrahedrons linked by ionic bonds [16]. The impact of Ag and $\mathrm{Ti}$ on the thermal characteristics was described.

Thermograms are presented in Figure 2.a for Ag-doped glasses and 2.b for Ti-doped glasses.

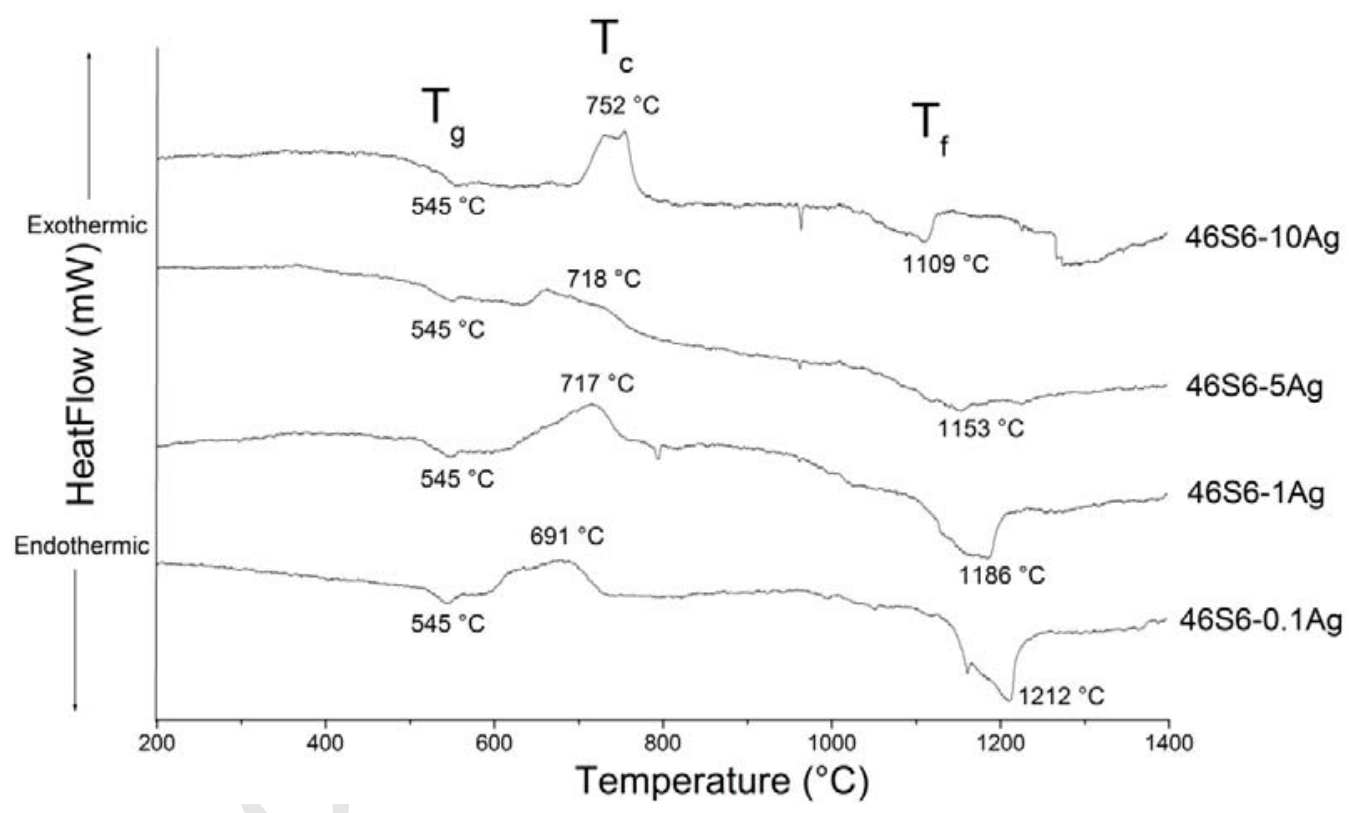

Figure 2.a: Thermograms of Ag-doped glasses 


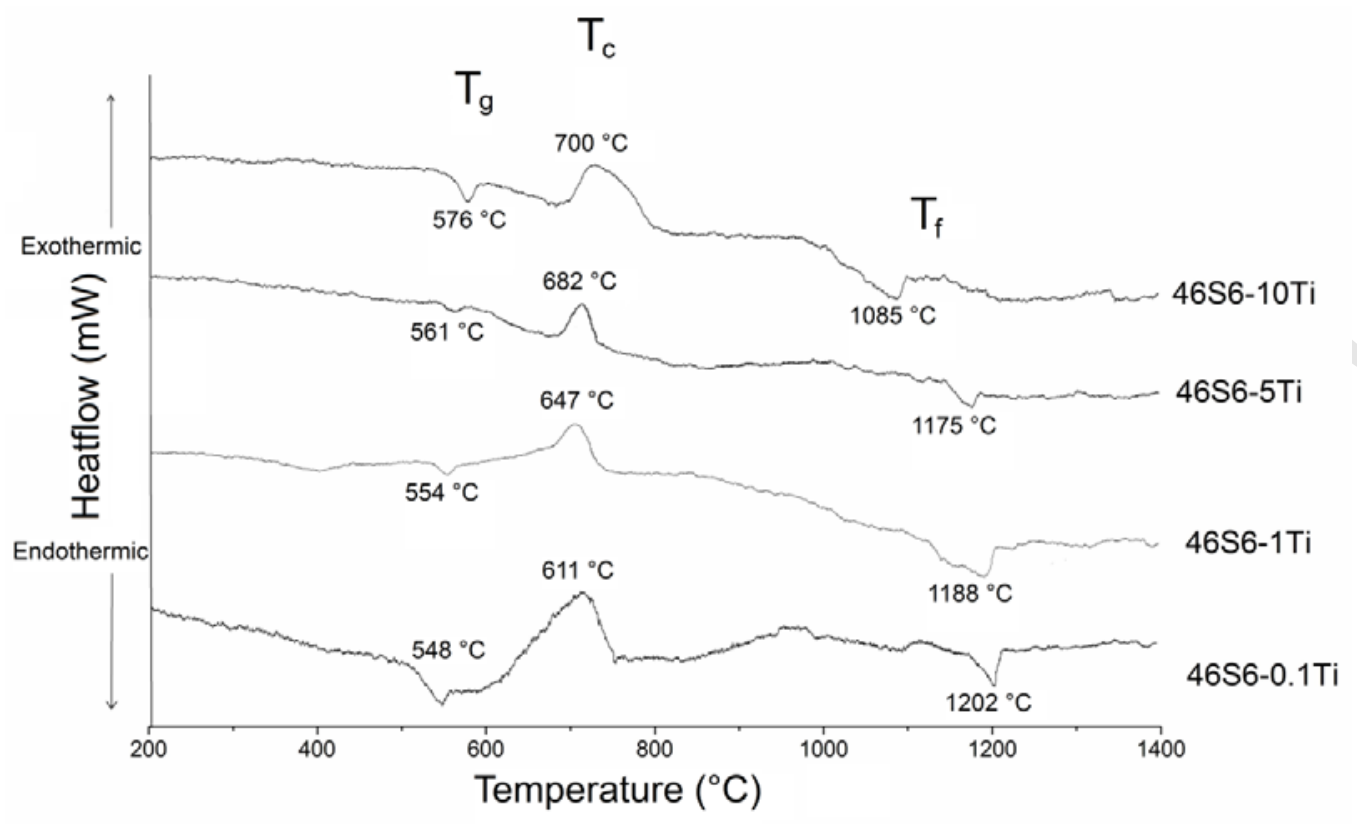

Figure 2.b: Thermograms of Ti-doped glasses

Each thermogram presents 3 peaks characteristics of glass transition, crystallization and fusion temperatures. To determine the start of crystallization phenomenon $\left(T_{\text {onset }} \mathrm{c}\right)$, the tangent method was used and the thermal characteristics of doped glasses are summarized in Table 2 and 3. $T_{\text {onset }} \mathrm{c}$ allows us to calculate the thermal stability of each glass according to the Dietzel relation.

\begin{tabular}{|c|c|c|c|c|}
\hline & $46 \mathrm{~S} 6-0.1 \mathrm{Ag}$ & $46 \mathrm{~S} 6-1 \mathrm{Ag}$ & $46 \mathrm{~S} 6-5 \mathrm{Ag}$ & $46 \mathrm{~S} 6-10 \mathrm{Ag}$ \\
\hline$L_{\mathrm{f}}$ & 100 & 64 & 38 & 28 \\
\hline$T_{\text {onset }} \mathrm{c}(\mathrm{K})$ & 873 & 891 & 913 & 966 \\
\hline$T_{\mathrm{g}}(\mathrm{K})$ & 818 & 818 & 818 & 818 \\
\hline $\mathrm{TS}(\mathrm{K})$ & 55 & 73 & 95 & 148 \\
\hline$T_{\mathrm{f}}(\mathrm{K})$ & 1485 & 1459 & 1426 & 1382 \\
\hline$\Delta S(\mathrm{~J} / \mathrm{K})$ & 66 & 45 & 26 & 18 \\
\hline
\end{tabular}

Table 2: Thermal characteristics of Ag-doped glasses

\begin{tabular}{|c|c|c|c|c|}
\hline & $46 \mathrm{~S} 6-0.1 \mathrm{Ti}$ & $46 \mathrm{S6} 6-1 \mathrm{Ti}$ & $46 \mathrm{~S} 6-5 \mathrm{Ti}$ & $46 \mathrm{S6}-10 \mathrm{Ti}$ \\
\hline$L_{\mathrm{f}}$ & 110 & 51 & 23 & 9 \\
\hline$T_{\text {onset }} \mathrm{c}(\mathrm{K})$ & 898 & 915 & 948 & 964 \\
\hline$T_{\mathrm{g}}(\mathrm{K})$ & 821 & 827 & 834 & 849 \\
\hline $\mathrm{TS}(\mathrm{K})$ & 77 & 88 & 114 & 115 \\
\hline$T_{\mathrm{f}}(\mathrm{K})$ & 1475 & 1461 & 1448 & 1358 \\
\hline$\Delta S(\mathrm{~J} / \mathrm{K})$ & 73 & 36 & 15 & 5 \\
\hline
\end{tabular}

Table 3: Thermal characteristics of Ti-doped glasses 
Characteristic temperatures versus the content of $\mathrm{Ag}$ or Ti are presented in Figure 3 and 4.

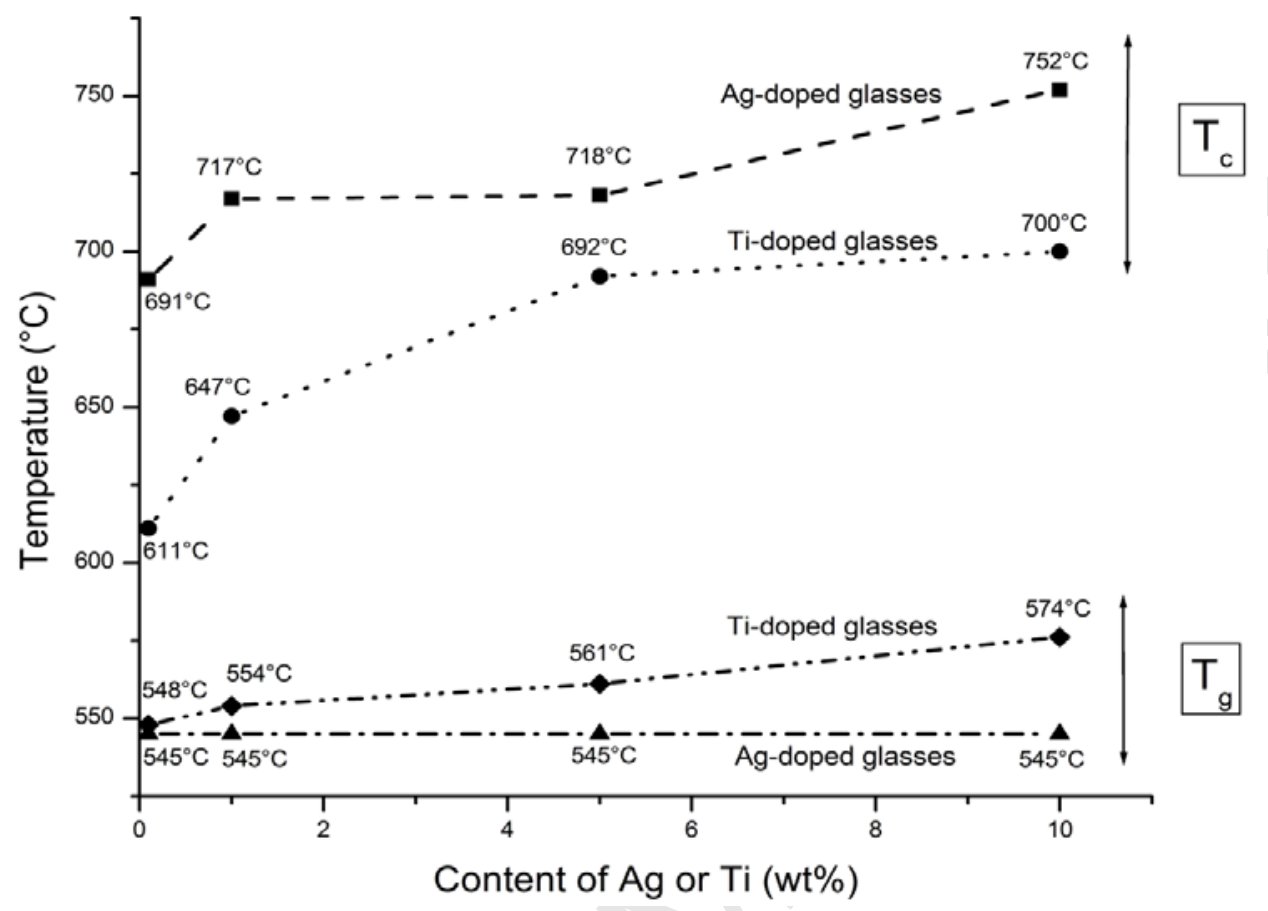

Figure 3: Crystallization and glass transition temperatures versus the content of $\mathrm{Ag}$ or $\mathrm{Ti}$

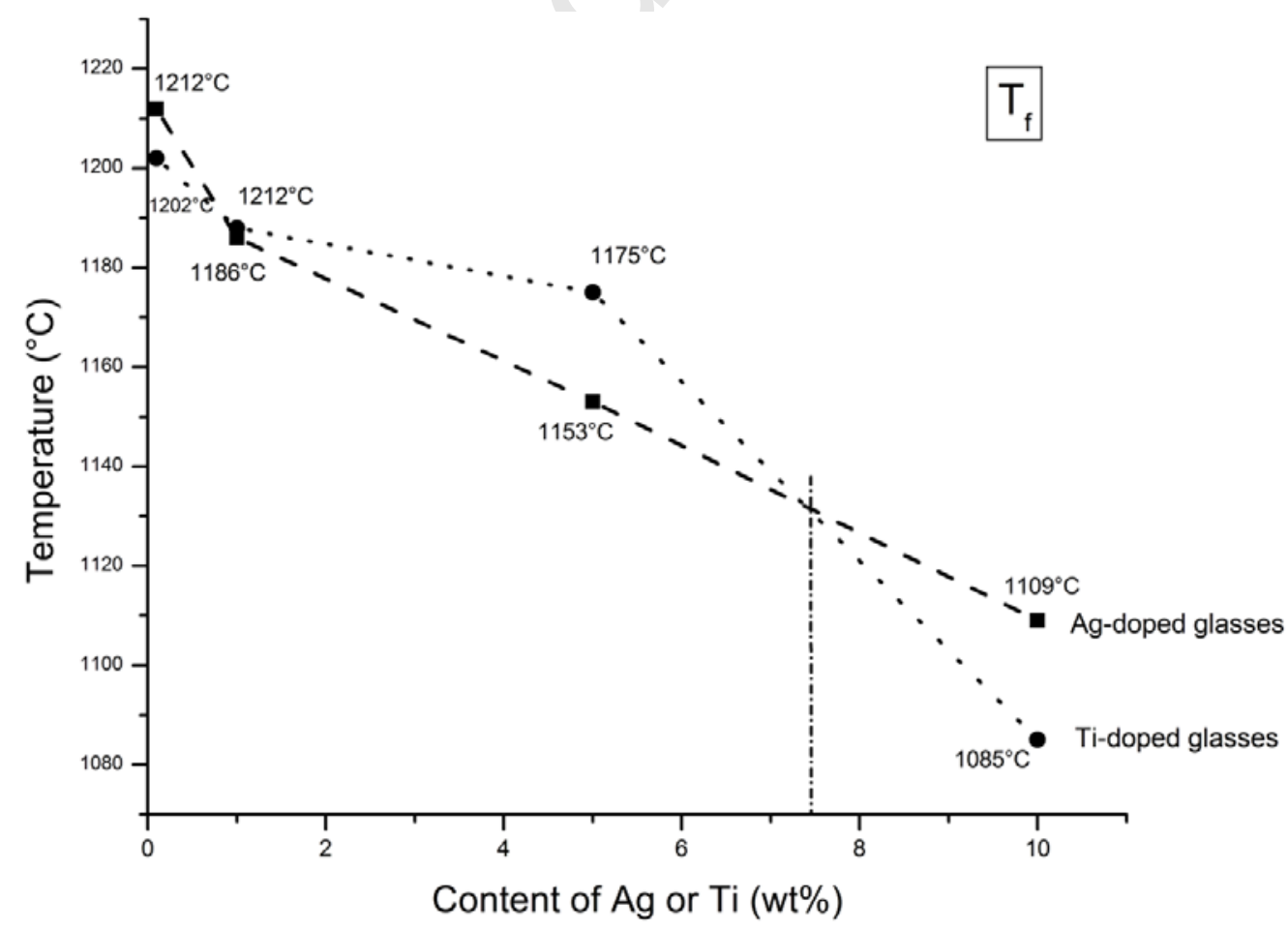

Figure 4: Fusion temperature versus the content of $\mathrm{Ag}$ or Ti. 
For Ag-doped glasses, a decrease of $T_{\mathrm{f}}$ (from 1212 up to $1109^{\circ} \mathrm{C}$ ), an increase of $T_{\mathrm{c}}$ (from 691 up to $\left.752^{\circ} \mathrm{C}\right)$ and a stabilization of $T_{\mathrm{g}}\left(545^{\circ} \mathrm{C}\right)$ are observed when the content of $\mathrm{Ag}$ increases. For Ti-doped glasses, variations are observed for the three characteristic temperatures. Indeed, $T_{\mathrm{g}}$ and $T_{\mathrm{c}}$ increase (from 548 up to $576^{\circ} \mathrm{C}$ for $\mathrm{Tg}$ and from $611^{\circ} \mathrm{C}$ up to $700^{\circ} \mathrm{C}$ for $\mathrm{Tc}$ ), $T_{\mathrm{f}}$ decreases (from 1202 up to $1085^{\circ} \mathrm{C}$ ) when the content of Ti increases in the glassy matrix. For $T_{\mathrm{g}}$ and $T_{\mathrm{c}}$, the same results are found in phosphate glasses [28].

In these results, important differences of temperature for $T_{\mathrm{c}}$ are observed between glasses doped with a low content of doping metal element and those with a high content. Indeed, for 46S6-0.1 Ag, $T_{\mathrm{c}}=691^{\circ} \mathrm{C}$ and for $46 \mathrm{~S} 6-10 \mathrm{Ag}, T_{\mathrm{c}}=752^{\circ} \mathrm{C}$ i.e. a difference $\Delta T_{\mathrm{c}}=+61^{\circ} \mathrm{C}$. For Ti-doped glasses, 46S6-0.1Ti presents a $T_{\mathrm{c}}=611^{\circ} \mathrm{C}$ and for $46 \mathrm{~S} 6-10 \mathrm{Ti}, T_{\mathrm{c}}=700^{\circ} \mathrm{C}$ i.e. $\Delta T_{\mathrm{c}}=$ $+89^{\circ} \mathrm{C}$. Thus, although Ag-doped glasses have larger crystallization temperatures, the introduction of $\mathrm{Ti}$ increases faster crystallization temperatures than the adding of $\mathrm{Ag}$. For glass transition temperatures, the effect of the two elements is less pronounced. Indeed, 46S6$0.1 \mathrm{Ti}$ and $46 \mathrm{~S} 6-10 \mathrm{Ti}$ present a $\Delta T_{\mathrm{g}}=+26^{\circ} \mathrm{C}$ while $46 \mathrm{~S} 6-0.1 \mathrm{Ag}$ and $46 \mathrm{~S} 6-10 \mathrm{Ag}$ have a $\Delta T_{\mathrm{g}}=$ $0^{\circ} \mathrm{C}$. Silver does not have effect on the glass transition temperature [23] whereas titanium increases it.

Moreover for each chemical composition, more the amount of doping element increases and more the thermal stability is high (up to $148 \mathrm{~K}$ for $46 \mathrm{~S} 6-10 \mathrm{Ag}$ and $115 \mathrm{~K}$ for $46 \mathrm{~S} 6-10 \mathrm{Ti}$ ) as shown in Figure 5. An important thermal stability reveals a low tendency to crystallization [16]. Here, silver have more important impact on the thermal stability because between 46S6$0.1 \mathrm{Ag}$ and $46 \mathrm{~S} 6-10 \mathrm{Ag}, \Delta \mathrm{TS}=93 \mathrm{~K}$ while between $46 \mathrm{~S} 6-0.1 \mathrm{Ti}$ and $46 \mathrm{~S} 6-10 \mathrm{Ti}, \Delta \mathrm{TS}=38 \mathrm{~K}$. Moreover, from $5 \mathrm{wt} \%$ of $\mathrm{Ti}$ introduced in the glassy matrix, TS tends to stabilize around 115 $\mathrm{K}$. 


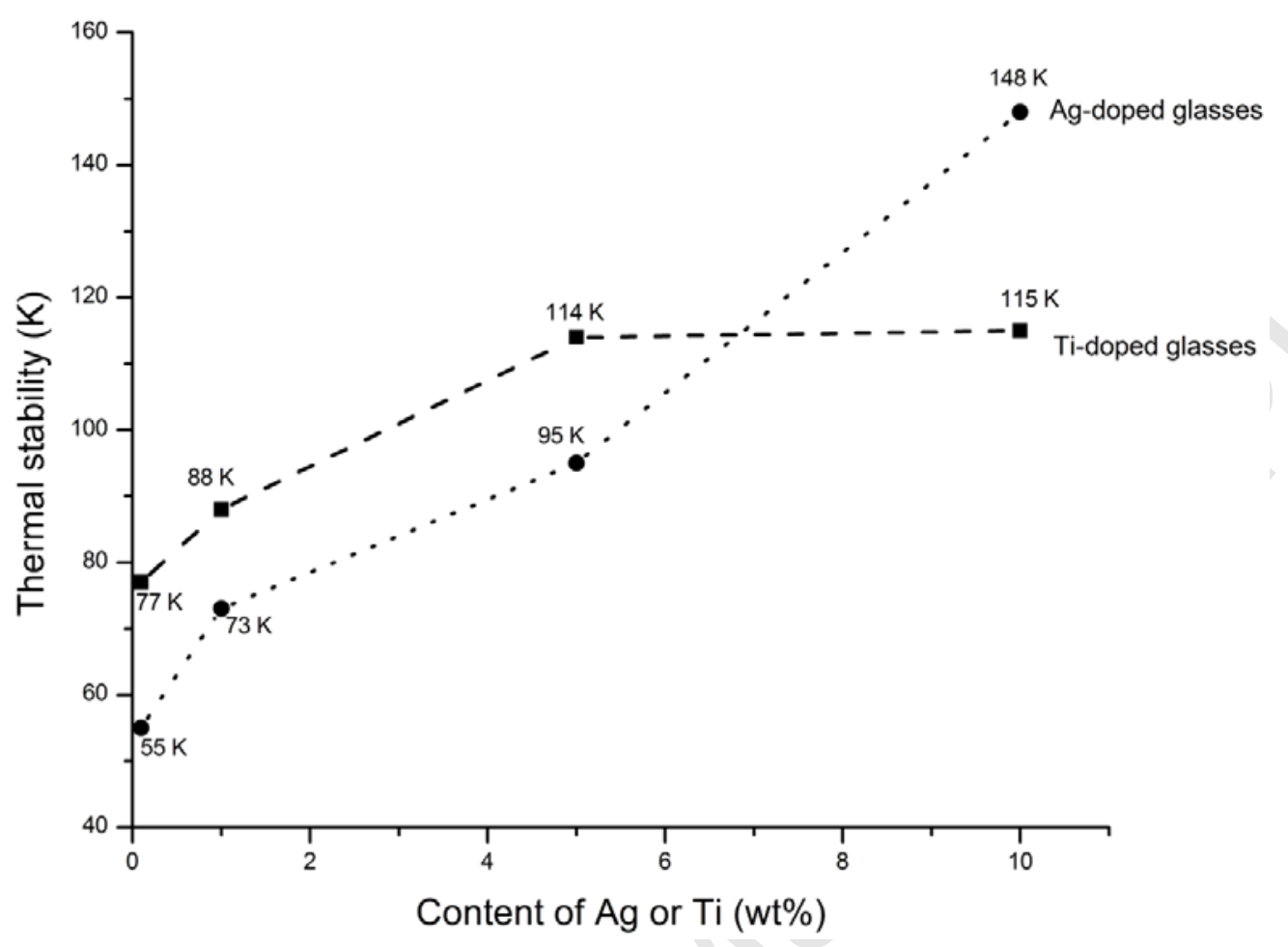

Figure 5: Thermal stability versus the content of Ag or Ti.

The most significant effect, caused by the introduction of $\mathrm{Ti}$ or $\mathrm{Ag}$, is the reduction of the melting temperature. Between 46S6-0.1 Ag and 46S6-10Ag, $\Delta T_{\mathrm{f}}=-103^{\circ} \mathrm{C}$ and for $46 \mathrm{~S} 6-0.1 \mathrm{Ti}$ and $46 \mathrm{~S} 6-10 \mathrm{Ti}, \Delta T_{\mathrm{f}}=-117^{\circ} \mathrm{C}$. Furthermore, at low contents, the melting temperatures of the doped glasses are very close up to $1 \mathrm{wt} \% \mathrm{Ti}$ or $\mathrm{Ag}$ introduced. Beyond $1 \mathrm{wt} \%$, silver decreases faster the melting temperature than titanium. Approximately at $7.4 \mathrm{wt} \%$ of doping element introduced, there is an inversion behavior and titanium reduces faster the fusion temperature than silver.

When the doping metallic oxides are introduced in the amorphous matrix, the covalent Si-O$\mathrm{Si}$ chemical bonds were broken to create metal-oxygen ionic bonds. As covalent bonds are stronger energetically than metal-oxygen bonds formed, changes in the thermal behavior of glasses are observed. For Ag-doped glasses, by FTIR, Si-O-Si chemical bonds were formed with the increase of the content of Ag in the glass matrix. The chemical characteristics of Ti and Ag (Table 1) may explain the changes in the thermal behavior. Indeed, the reduction of melting temperatures for Ag-doped glasses is faster contrast to those Ti-doped glasses which start to decrease from $5 \mathrm{wt} \%$ of Ti introduced. The melting points of the introduced metal elements can explain this phenomenon. Silver have a melting point of $962^{\circ} \mathrm{C}$ while titanium 
has a melting point to $1660{ }^{\circ} \mathrm{C}$, hence the difficulty, at the start, to reduce the fusion temperature of Ti-doped glasses. In the end, the glasses doped with $10 \mathrm{wt} \%$ of $\mathrm{Ti}$ or $\mathrm{Ag}$ reach a near fusion temperature $\left(1085^{\circ} \mathrm{C}\right.$ for $46 \mathrm{~S} 6-10 \mathrm{Ti}$ and $1109^{\circ} \mathrm{C}$ for $\left.46 \mathrm{~S} 6-10 \mathrm{Ag}\right)$. This decrease is later for Ti-doped glasses.

These results allow understanding the thermal behavior of glasses. The adding of $\mathrm{Ag}$ and $\mathrm{Ti}$ in the vitreous network has a high impact on the fusion temperature and a less impact on the crystallization and glass transition temperatures. In a previous work [16], the effect of Zn was studied in order to elaborate a protocol of synthesis of a porous biomaterial. This present study can bring informations about the behavior of glasses during in vitro assays and their capacity to exchange ionic elements to form hydroxyapatite crystals. Therefore, we could adapt the use of $\mathrm{Ag}$ and $\mathrm{Ti}$ in the porous biomaterial to improve its physiological properties and to use it into broader medical applications.

The following Table 4 shows changes in the thermal characteristics of other biomaterials to compare with synthesized glasses. The same trends are found in the changes of thermal characteristics.

\begin{tabular}{|c|c|c|c|c|}
\hline Biomaterials & $\mathrm{T}_{\mathrm{g}}\left({ }^{\circ} \mathrm{C}\right)$ & $\mathrm{T}_{\mathrm{c}}\left({ }^{\circ} \mathrm{C}\right)$ & $\mathrm{T}_{\mathrm{f}}\left({ }^{\circ} \mathrm{C}\right)$ & References \\
\hline $46 \mathrm{~S} 6-1 \mathrm{Ti}$ & 554 & 647 & 1188 & - \\
\hline $46 \mathrm{S6}-1 \mathrm{Ag}$ & 545 & 717 & 1186 & - \\
\hline $\begin{array}{c}98\left[0.5 \mathrm{ZnO}-0.1 \mathrm{~B}_{2} \mathrm{O}_{3}-\right. \\
\left.0.4 \mathrm{P}_{2} \mathrm{O}_{5}\right] .2 \mathrm{TiO}_{2}\end{array}$ & 492 & 634 & 898 & {$[18]$} \\
\hline $\begin{array}{c}96.1\left[0.5 \mathrm{ZnO}-0.1 \mathrm{~B}_{2} \mathrm{O}_{3}-\right. \\
\left.0.4 \mathrm{P}_{2} \mathrm{O}_{5}\right] .3 .9 \mathrm{TiO}_{2}\end{array}$ & 502 & 651 & 884 & {$[18]$} \\
\hline Pure PVA & 86 & - & 192 & {$[32]$} \\
\hline Ag-PVA & 97 & - & 187 & {$[32]$} \\
\hline
\end{tabular}

Table 4: Thermal characteristics of other biomaterials.

\subsection{Excess entropy of doped bioactive glasses.}

The aim of this part is to calculate the excess entropy of each glass and to evaluate the effect of the content of doping metal elements on this value. The principle consists to calculate the entropy at $0 \mathrm{~K}$. The formula to calculate the excess entropy has been established in a previous article [16]. The proof is as follows: 
The entropy of the liquid $S_{l}$ at a temperature $T>T_{\mathrm{f}}$ by the way crystal to liquid is [25]:

$$
S_{\mathrm{l}}=S_{0}+\int_{0}^{T_{\mathrm{f}}} C p_{\mathrm{s}} \frac{\mathrm{d} T}{T}+\frac{\Delta H_{\mathrm{f}}}{T_{\mathrm{f}}}+\int_{T_{\mathrm{f}}}^{\mathrm{T}} C p_{\mathrm{l}} \frac{\mathrm{d} T}{T}
$$

Where: $C \mathrm{p}_{\mathrm{s}}$ : specific heat of crystalline solid

$C p_{1}:$ specific heat of liquid, supercooled liquid or glass

$S_{0}$ corresponds to the entropy of the crystal at $T=0 \mathrm{~K} . S_{0}=0$ according to the third principle of thermodynamic.

The same relation of $S_{1}$ is obtained by the way glass to liquid [25]. The corresponding equation is:

$$
S_{\mathrm{l}}=S_{0}^{\prime}+\int_{0}^{T_{\mathrm{g}}} C p_{1} \frac{\mathrm{d} T}{T}+\int_{T_{\mathrm{g}}}^{T_{\mathrm{f}}} C p_{1} \frac{\mathrm{d} T}{T}+\int_{T_{\mathrm{f}}}^{T} C p_{1} \frac{\mathrm{d} T}{T}
$$

The identification of the two equations conducts to the establishment of the entropy $S_{0}$ of glass at $T=0 \mathrm{~K}$. This relation is:

$$
S_{0}^{\prime}=\frac{\Delta H_{\mathrm{f}}}{T_{\mathrm{f}}}-\int_{0}^{T_{\mathrm{f}}}\left(C p_{\mathrm{l}}-C p_{\mathrm{s}}\right) \frac{\mathrm{d} T}{T}
$$

The variation of the entropy can be deducted by the following relation:

$$
\Delta S=S \text { (liquid or glass) }-S(\text { crystal) }
$$

At a temperature $T<T_{\mathrm{f}}$ :

$$
\Delta S=\frac{\Delta H_{\mathrm{f}}}{T_{\mathrm{f}}}-\int_{T_{\mathrm{g}}}^{T_{\mathrm{f}}}\left(C p_{\mathrm{l}}-C p_{\mathrm{s}}\right) \frac{\mathrm{d} T}{T}
$$




$$
\Delta S=\frac{\Delta H_{f}}{T_{f}}-2.09 \operatorname{Ln} \frac{T_{f}}{T_{g}}+0.48 \times 10^{-3}\left[T_{f}-T_{g}\right]
$$

Obtained results reveal that values obtained for doped bioactive glasses are not equal to zero. The excess entropy of pure glass is $79 \mathrm{~J} / \mathrm{K}$ [13]. The obtained excess entropy is from 66 up to $18 \mathrm{~J} / \mathrm{K}$ for Ag-doped glasses and from 73 up to $5 \mathrm{~J} / \mathrm{K}$ for Ti-doped glasses. The presence of metal elements $\mathrm{Ag}$ or $\mathrm{Ti}$ in the amorphous matrix reduces this excess entropy which varies depending on the content of metal element in the glass matrix as shown in Figure 6. The results are in agreement with the J. Zarzycki theory. The third principle of thermodynamic cannot be applied to bioactive glasses elaborated in the quaternary system $\mathrm{SiO}_{2}-\mathrm{CaO}-\mathrm{Na}_{2} \mathrm{O}-$ $\mathrm{P}_{2} \mathrm{O}_{5}$. These results will contribute on the comprehension of the changes of the kinetic of bioactivity of doped bioactive glasses compared to pure glass [16-29].

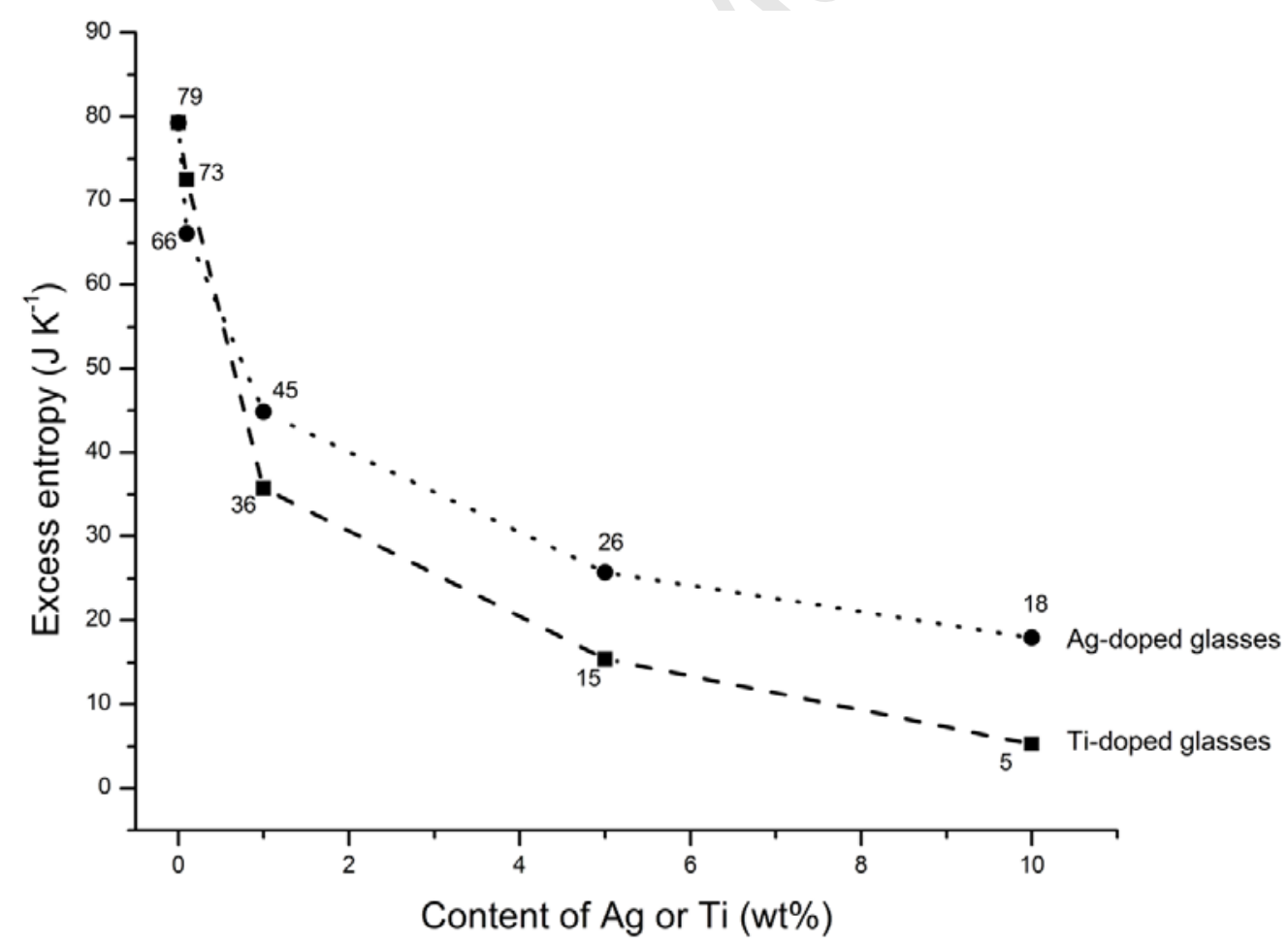

Figure 6: Excess entropy versus the content of Ag or Ti.

Crystals present zero entropy at $0 \mathrm{~K}$, i.e. there is no thermal agitation of atoms which become motionless. The decrease of the entropy of glasses with the increase of doping elements 
means that the disorder is reduced in the glass matrix and the atoms present become increasingly immobile. This decrease of the disorder is related to the size of atoms constituting the glass matrix and their electronegativity (property explaining the ability of an atom to attract another and the formation of bonds between atoms).

Titanium is bigger than that of silver (atomic radius of $176 \mathrm{pm}$ versus $160 \mathrm{pm}$ respectively). On the contrary, the electronegativity of silver is greater than that of titanium (1.93 versus 1.54). Thereby, the values of excess entropy 46S6-10Ag glasses (18 J/K) and 46S6-10Ti (5 $\mathrm{J} / \mathrm{K}$ ) can be explained by these previous properties. The size of atoms is a more important characteristic that the electronegativity. Indeed, for Ti-doped glasses, when the titanium content increases, titanium atoms cannot be thermally agitated compared to silver atoms which would reduce the entropy up to a value of $5 \mathrm{~J} / \mathrm{K}$ for $46 \mathrm{~S} 6-10 \mathrm{Ti}$. For silver, the atomic radius is smaller and the entropy of Ag-doped glasses decreases. However, the entropy of $46 \mathrm{~S} 6-10 \mathrm{Ag}$ is greater by a factor of 3.6 compared to 46S6-10Ti. The atomic radius of silver being smaller than that of titanium, atoms can easily move in the glass matrix hence largest entropy. The capacity of created chemical bonds in the glass matrix, due to its important electronegativity, may explain the decrease of entropy in the Ag-doped glasses. Thereby, atomic characteristics of the introduced doping elements are important to explain the variations of entropy.

The change of entropy may also be attributed at the problems of residual thermal stress, which can exist in biomaterials. This may have contributed to the change in entropy of the biomaterial with higher concentrations of $\mathrm{Ti}$ and $\mathrm{Ag}$ in their compositions. Indeed, mechanical and thermal properties depend on not only of the chemical composition but also of the residual thermal stress (tensile and compressive stress) which appears during the cooling of the glass matrix. The residual thermal stress can appear during a non-homogeneous cooling [30]. Tejedor and al [31], with their metallic glasses, have proved that the decrease of the residual stresses begins with an annealing process (30 minutes at different temperatures) and when the temperature reaches a precise value, the residual stresses are completely removed.

All our glasses were synthesized with the same process. The casting was carried out at 1350 ${ }^{\circ} \mathrm{C}$ in molds preheated to $565{ }^{\circ} \mathrm{C}$ with a $\Delta \mathrm{T}=+20{ }^{\circ} \mathrm{C}$ compared to the $\mathrm{T}_{\mathrm{g}}$ of the $46 \mathrm{~S} 6$. The glass was annealed for 4 hours at $565^{\circ} \mathrm{C}$ and the decrease of the temperature up to ambient temperature was made according to a heating rate of $1{ }^{\circ} \mathrm{C} / \mathrm{min}$. The time of annealing is long 
and the rate of the cooling is low which allows eliminating residual mechanical stresses. Indeed, all our glasses have been cut, sliced, drilled and machined. Thereby, the residual thermal stresses, if they are present, are negligible to evaluate the change of entropy.

\section{Conclusions}

The X-ray diffraction of doped bioactive glasses highlight the amorphous character of all glasses up to $10 \mathrm{wt} \%$ of metal elements introduced in the vitreous network. Moreover, the infrared spectroscopy indicates us that different chemical bonds form according to the introduced element.

The adding of silver or titanium in the glass matrix involves several changes in the thermal characteristics. Fusion temperatures clearly decrease when the amount of these metal elements increases. Variations are observed also on the crystallization and glass transition temperatures. Moreover, the introduction of metal elements increases the thermal stability of glasses.

The calculated excess entropy shows that the pure glass have more important excess entropy compared to doped glasses. The presence of metal elements in the glass matrix reduces the excess entropy according to the content of metal introduced. The disorder of the material defined by the entropy decreases with the adding of metal elements in the glass matrix probably due to the formation of metal-oxygen chemical bond that may structure the glass network. The size of atoms may also influence the disorder in the glass network.

The present study allows us to understand the thermal behavior of bioactive doped glasses which could have an influence on their chemical reactivity and on their bioactivity. Biomaterials could be adapted in the synthesis of porous biomaterial established in a previous work and in different medical applications by introducing chemical interesting elements having good physiological properties.

\section{References}

[1] L.L. Hench, Bioceramics: From Concept to Clinic, J Am Ceram Soc. 74 (1991) 14871510 . 
[2] G. Daculsi, O. Malard, E. Goyenvalle, Efficacité et performance des substituts osseux pour remplacer les allogreffes et autogreffes, ITBM-RBM. 26 (2005) 218-222.

[3] L.L. Hench, Genetic design of bioactive glass, J Eur Ceram Soc. 29 (2009) 1257-1265.

[4] E. Wers et al, Effect of copper and zinc on the bioactivity and cells viability of bioactive glasses, Bioceram Dev Appl. S:1 (2013).

[5] H. Oudadesse, E. Dietrich, Y. Le Gal, P. Pellen, B. Bureau, A.A. Mostafa, G. Cathelineau, Apatite forming ability and cytocompatibility of pure and Zn-doped bioactive glasses, Biomed Mater. 6 (2011) 11-17

[6] E. Ditriech, H. Oudadesse, A. Lucas-Girot, M. Mami, In vitro bioactivity of melt-derived glass 46S6 doped with magnesium, Biomed Mater. 2 (2007) 59-64.

[7] M. Niinomi, Mechanical properties of biomedical titanium alloys, Mat Sci Eng A. 243 (1998) 231-236.

[8] M. Bellantone, N.J. Coleman, L.L. Hench, Bacteriostatic action of a novel fourcomponent bioactive glass, J Biomed Mater Res. 51 (2000) 484-490.

[9] G. Zhao, S.E. Stevens, Multiple parameters for the comprehensive evaluation of the susceptibility of Escherichia coli to the silver ion, Biomaterials. 11 (1998) 27.

[10] A. Yoshiki, M. Hiroshi, N. Iwao, S. Nobuko, A. Tomonori, S. Takafumi, Masaki, M. Masaaki, H. Takao, Calcium phosphate coating containing silver shows high antibacterial activity and low cytotoxicity and inhibits bacterial adhesion, Mater. Sci. Eng. C 30 (2010) 175-180.

[11] T. Toshikazu, Antimicrobial agent composed of silica-gel with silver complex, Inorg. Mater. 6 (1999) 505-511.

[12] B. Li, X. Liua, F. Meng, J. Chang, C. Ding, Preparation and antibacterial properties of plasma sprayed nano-titania/silver coatings, Mater Chem Phys. 118 (2009) 99-104.

[13] M. Bosetti, A. Mass, E. Tobin, M. Cannas, Silver coated materials for external fixation devices: "in vitro" biocompatibility and genotoxicity, Biomaterials 23 (2002) 887-892. 
[14] A.M. El-Kady, A.F Ali, R.A Rizk, M.M Ahmed, Synthesis, characterization and microbiological response of silver doped bioactive glass nanoparticles, Ceram Int. 38 (2012) $177-188$.

[15] M. Bellantone, H.D Williams, L.L. Hench, Broad-spectrum bactericidal activity of $\mathrm{Ag}_{2} \mathrm{O}$-doped bioactive glass, Antimicrob Agents Chem. 6 (2002) 1940-1945.

[16] E. Wers, H. Oudadesse, Thermal behaviour and excess entropy of bioactive glasses and Zn-doped glasses, J Therm Anal Calorim (2013) 1-8

[17] J. Barton, C. Guillemet, Le verre: science et technologie. EDP Science, Les Ulis, 2004

[18] J. Pospisil, P. Mosner, L. Koudelka, Thermal behaviour and crystallization of titaniumzinc borophosphate glasses, J Therm Anal Calorim. 84 (2006) 479-82.

[19] P. Mosner, K. Vosejpkova, L. Koudelka, Thermal behaviour and properties of $\mathrm{Na}_{2} \mathrm{O}-$ $\mathrm{TiO}_{2}-\mathrm{P}_{2} \mathrm{O}_{5}$ glasses, J Term Anal and Calorim. 96 (2009) 469-74.

[20] J. Park, A. Ozturk, Effect of $\mathrm{TiO}_{2}$ addition on the crystallization and tribological properties of $\mathrm{MgO}-\mathrm{CaO}-\mathrm{SiO}_{2}-\mathrm{P}_{2} \mathrm{O}_{5}-\mathrm{F}$ glasses, Thermochim Acta. 470 (2008) 60-66.

[21] A. Kumar, P.B. Barman, R. Sharman, Crystallization kinetics of Ag-doped Se-Bi-Te chalcogenide glasses, J Therm Anal Calorim. (2013).

[22] M. Iqbad, M. McCullough, A. Harris, S. Holger Eichborn, Thermal conductivity of polyurethane composites containing nanometer- and micrometer-sized silver particles, $\mathrm{J}$ Therm Anal Calorim. 108 (2012) 933-38.

[23] N. Zotov, C. Wagner, F. Bellido, L.M. Rodriguez, R. Jimenez-Garay, Thermal analysis of Ag-As-Se chalcogenide glasses, Thermochim Acta. 296 (1997) 23-29.

[24] K. Chrissafis, E.Pavlidou, D.Gkogkou, D. Bikiaris, Effect of Cu-nanofibers and Ag nanoparticles on syndiotactic polystyrene thermal stability and on its decomposition mechanism, Thermochim Acta. 561 (2013) 26-35.

[25] J. Zarzycki, Les verres et l'état vitreux, Masson, Paris, 1982. 
[26] A. Dietzel. Glasstruktur und Glaseigenschaften. Glass Technol. (1968) 22-41.

[27] A.M.B. Silva, R.N. Correia, J.M.M. Oliveira, M.H.V. Fernandes, Structural characterization of $\mathrm{TiO}_{2}-\mathrm{P}_{2} \mathrm{O}_{5}-\mathrm{CaO}$ glasses by spectroscopy, J Eur Ceram Soc 30 (2010) $1253-1258$.

[28] E. Ali Abou Neel, W. Chrzanowski, J.C. Knowles, Effect of increasing titanium dioxide content on bulk and surface properties of phosphate-based glasses, Acta biomaterialia. 4 (2008) 523-534.

[29] E. Dietrich, H. Oudadesse, A. Lucas-Girot, Y. LeGal, S. Jeanne, G. Cathelineau, Effects of $\mathrm{Mg}$ and $\mathrm{Zn}$ on the surface of doped melt-derived glass for biomaterials applications, Appl Surf Sci. 255 (2008) 391-395.

[30] L.H. Adams, The annealing of glass as a physical problem, Journal of the Franklin Institute 216 (1933) 39-71.

[31] M. Tejedor, J.A. Garc, J. Carrizo, L. Elbaile, Influence of thermal treatments on the internal stresses of metallic glasses, J Non Cryst Sol 235-237 (1998) 793-795.

[32] A. Nimrodh Ananth, S. Umapathy, J. Sophia, T. Mathavan, D. Mangalaraj, On the optical and thermal properties of in situ/ex situ reduced AgNP's/PVA composites and its role as a simple SPR-based protein sensor, Appl Nanosci 1 (2011) 87-96. 
Thermal investigations of Ti and Ag-doped bioactive glasses.

\section{Highlights}

- The adding of $\mathrm{Ag}$ or $\mathrm{Ti}$ involves different variations on the $\mathrm{T}_{\mathrm{g}}$ and $\mathrm{T}_{\mathrm{c}}$

- The introduction of $\mathrm{Ag}$ or $\mathrm{Ti}$ decreases the $\mathrm{T}_{\mathrm{f}}$ of bioactive glasses

- Increasing addition of $\mathrm{Ag}$ or $\mathrm{Ti}$ decreases the excess entropy 